\title{
Messenger Ribonucleoprotein Particles from Plant Cell Cultures
}

Jörg Pfisterer

Institut für Botanik, Technische Universität, Hannover

Z. Naturforsch. 33 c, 359-362 (1978) ; received March 20, 1978

Plant Cell Cultures, Polysomes, mRNP Particles, mRNA/poly (A)

Messenger ribonucleoprotein particles were isolated from the polysomes of logarithmically growing plant cell cultures, pulse-labeled with $\left[{ }^{3} \mathrm{H}\right]$ adenosine for $30 \mathrm{~min}$. More than $80 \%$ of the labeled RNP was present in particles sedimenting between $80 \mathrm{~S}$ and $30 \mathrm{~S}$ on sucrose density gradients, but was not associated with ribosomal subunits. The size distribution differs from those reported for polysomal mRNP particles to date. After fixation with glutaraldehyde the labeled RNP particles had a buoyant density of $1.38 \mathrm{~g} / \mathrm{cm}^{3}$ in $\mathrm{CsCl}$ gradients. Radioactively labeled RNA extracted from the RNP particles showed a heterodisperse size distribution and contained poly (A) stretches as determined by affinity chromatography and ribonuclease digestion experiments.

\section{Introduction}

Ribonucleoprotein particles containing mRNA have been studied intensively in mammalian cells [1], but to date there is only little information available on mRNP particles from cells of higher plants. mRNP particles free in the cytoplasm have been shown to represent the "preformed mRNA" found in dry seeds [2], and their synthesis has been studied in developing plant embryos [3, 4]. Newly synthesized RNP particles bearing heterogeneous RNA have also been found in nuclei of developing seeds $[5,6]$. There is only one report, however, on polysomal mRNP particles from plant cells [7], although these represent the fraction actively involved in protein synthesis rather than transport or storage forms.

In this report some of the properties of $\mathrm{mRNP}$ particles released from polysomes are described. Rapidly proliferating plant cell cultures were used as a source of well defined and homogeneous cell material.

\section{Materials and Methods}

Plant cell cultures originating from root explants of Petroselinum sativum (parsley) were grown as described [8]. To prepare labeled RNP particles, five days old cultures were labeled for $30 \mathrm{~min}$ with $\left[2-{ }^{3} \mathrm{H}\right]$ adenosine $(2 \mu \mathrm{Ci} / \mathrm{ml}$; specific activity $21 \mathrm{Ci} /$ $\mathrm{mmol})$. The cultures were then rapidly cooled, and

Abbreviations: RNP, ribonucleoprotein; TCA, trichloroacetic acid.

Requests for reprints should be sent to Dr. Jörg Pfisterer, Dept. of Physiology and Biophysics, University of Illinois, 524 Burrill Hall, Urbana, Il. 61801, USA. the cells were washed, resuspended in buffer A $(0.2 \mathrm{M}$ Tris- $\mathrm{HCl} \mathrm{pH} 8.5,0.2 \mathrm{M}$ sucrose, $30 \mathrm{~mm}$ $\mathrm{MgCl}_{2}, 60 \mathrm{~mm} \mathrm{KCl}$ ) and broken with a Teflon-glass homogenizer. The homogenate was centrifuged for $5 \mathrm{~min}$ at $1500 \times \mathrm{g}$ to remove cell debris and nuclei. The supernatant was made $2 \%$ of Triton X-100 and recentrifuged for $5 \mathrm{~min}$ at $29000 \times \mathrm{g}$. The resulting supernatant was filtered through nylon gauze, layered over $5 \mathrm{ml}$ cushions of $1.5 \mathrm{M}$ sucrose in buffer B (40 mM Tris-HCl pH 8.5, $10 \mathrm{~mm} \mathrm{MgCl}_{2}$, $20 \mathrm{~mm} \mathrm{KCl}$ ) and centrifuged for 2 hours at $105000 \times g$. The polysomal pellets were resuspended in buffer C (20 mM Tris-HCl pH 8.5, $10 \mathrm{~mm} \mathrm{MgCl}_{2}$, $20 \mathrm{~mm} \mathrm{KCl}$ ) containing $50 \mathrm{~mm}$ EDTA and incubated for $30 \mathrm{~min}$ at $0^{\circ} \mathrm{C}$. After sedimentation of insoluble material at low speed $(5000 \times g)$, aliquots of the clear supernatant were layered onto $12 \mathrm{ml}$ linear gradients of $10-30 \%$ sucrose in buffer C containing $50 \mathrm{~mm}$ EDTA. The gradients were centrifuged for $6.5 \mathrm{~h}$ at $202000 \times g$ in an SW 40 rotor and fractionated. The absorbance at $260 \mathrm{~nm}$ was monitored, and the radioactivity of the fractions was determined after precipitation with cold $5 \%$ TCA.

RNA was extracted from EDTA-dissociated polysomes by the phenol-chloroform method of Perry et al. [9]. Sedimentation analysis of the RNA was performed using linear $12 \mathrm{ml}$ gradients of $10-30 \%$ sucrose in sarkosyl buffer ( $10 \mathrm{~mm}$ Tris- $\mathrm{HCl} \mathrm{pH} 7.8$, $0.1 \mathrm{~m} \mathrm{NaCl}, 10 \mathrm{~mm}$ EDTA, 0.5\% sarkosyl) as described [10]. Centrifugation was for $18 \mathrm{~h}$ at $113500 \times g$ in an SW 40 rotor. The profiles of absorbance at $260 \mathrm{~nm}$ and of radioactivity were recorded.

Poly (A) -content of the RNA was determined by affinity chromatography using poly(U)-Sepharose 
4. B (Pharmacia) according to Lindberg and Persson [10]. Ribonuclease digestion $(10 \mu \mathrm{g} / \mathrm{ml}$ pancreatic RNase and $1 \mu \mathrm{g} / \mathrm{ml} \mathrm{T}_{1}$ RNase) was performed by the method of Adesnik and Darnell [11].

In order to estimate the buoyant density of the RNP particles, they were fixed with glutaraldehyde according to Baltimore and Huang [12] and centrifuged through a preformed gradient of $\mathrm{CsCl}$ in buffer D (10 mM Tris-HCl pH 7.4, $10 \mathrm{~mm} \mathrm{NaCl}$, $1.5 \mathrm{mM} \mathrm{MgCl}_{2}, 0.8 \%$ Brij-58) for $5 \mathrm{~h}$ at $178000 \times g$ in an SW 65 rotor. Fractions recovered from the gradient were analyzed for density by refractive index measurement, for absorbance at $260 \mathrm{~nm}$ and for radioactivity precipitable by cold $5 \%$ TCA.

\section{Results and Discussion}

The isolation of intact polysomes from parsley cell cultures has been described in a previous report $[13]$. $\left[{ }^{3} \mathrm{H}\right]$ adenosine labeled polysomes were dissociated by EDTA under low salt conditions and the released material was analyzed by sucrose gradient centrifugation. The resulting radioactivity profile (Fig. 1) shows a heterodisperse population of particles sedimenting mainly between $80 \mathrm{~S}$ and 30S. There was only a small amount of labeled material with an $\mathrm{S}$ value greater than $80 \mathrm{~S}$. The UV absorption profile shows that the polysomes were completely dissociated into subunits, but the distribution of label along the gradient did not correspond with the absorption profile indicating that the label was present in species other than ribosomal subunits. Similar distribution patterns were obtained when the dissociated polysomes were analyzed on isokinetic sucrose gradients. The sedimentation values of $80 \mathrm{~S}$ to $30 \mathrm{~S}$ differ markedly from the size distribution reported by Ajtkhozhin et al. [7] for polysomal mRNP particles of germinating wheat embryos, where a large proportion of the EDTAreleased material sediments higher than $80 \mathrm{~S}$ or lower than 40S. A specific loss of large particles by the methods used here can be ruled out, however, since the sedimentation pattern of RNA extracted from EDTA-dissociated material is very similar to that of total polysomal RNA.

The size distribution of mRNP particles has been reported to depend on the ionic strength of the media used for their preparation [14]. This is not the case for the polysomal RNP particles described here, as dissociation of the polysomes in buffer $\mathrm{C}$ containing $250 \mathrm{mM} \mathrm{KCl}$ did not result in any change of the sedimentation profiles (not shown). Labeling of the cells for a longer period (up to $60 \mathrm{~min}$ ) also had no influence on the distribution pattern of the RNP particles [3]. Only when the cells had been labeled for more than one hour, an increasing amount of radioactivity appeared in the ribosomal subunits. These results indicate that the size distribution observed is no artifact produced by special conditions. Native free cytoplasmic mRNP particles from dry wheat embryos were recently shown to sediment in a similar range [15].

Sedimentation distribution of the RNA extracted from EDTA-dissociated polysomes is shown in Fig. 2. While distinct peaks of $4-5 \mathrm{~S}, 18 \mathrm{~S}$ and $25 \mathrm{~S}$ ribosomal RNA appear in the absorbance profile, the labeled material sediments in a broad region ranging from about $5 \mathrm{~S}$ to $28 \mathrm{~S}$ and exhibiting a

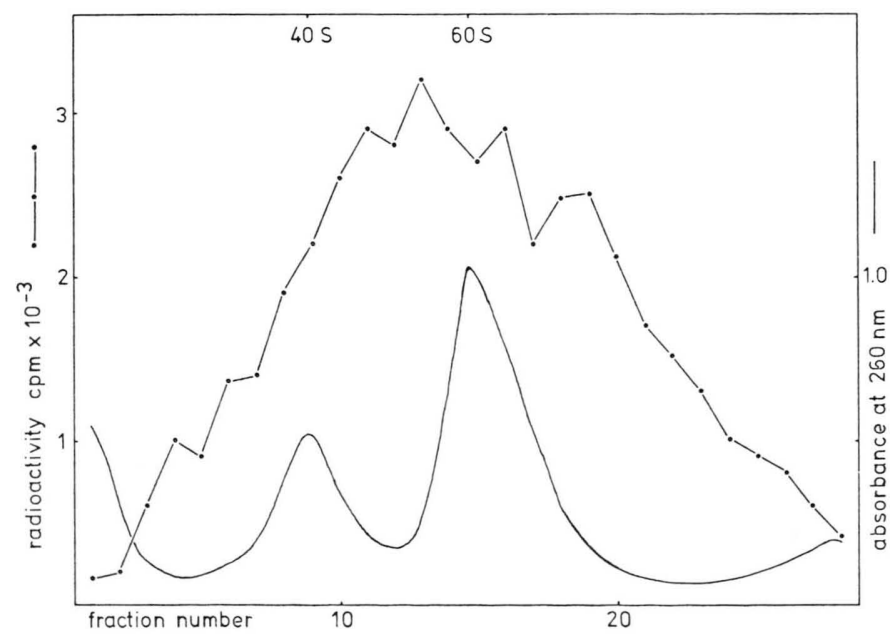

Fig. 1. Sedimentation distribution in a $10-30 \%$ linear sucrose gradient of RNP particles from EDTA-dissociated polysomes labeled with $\left[{ }^{3} \mathrm{H}\right]$ adenosine. Centrifugation was for $6.5 \mathrm{~h}$ at $202000 \times g$ as described in Materials and Methods. 


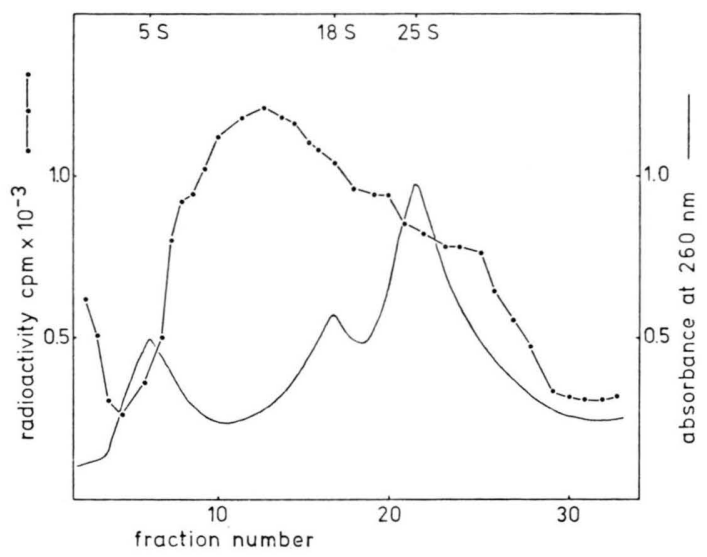

Fig. 2. Sedimentation distribution in a $10-30 \%$ linear sucrose gradient of $\left[{ }^{3} \mathrm{H}\right]$ adenosine labelled RNA extracted from EDTA-dissociated polysomes. Centrifugation was for $18 \mathrm{~h}$ at $113500 \times \mathrm{g}$ as described in Materials and Methods.

maximum at about $13 \mathrm{~S}$. Nearly $25 \%$ of this labeled RNA bound to poly(U)-Sepharose under high-salt conditions and could be released by washing with buffer containing 90\% formamide. Treatment with pancreatic and $T_{1}$ ribonuclease resulted in almost complete degradation of the RNA not retained by poly (U)-Sepharose, whereas more than $20 \%$ of the bound RNA were resistant to digestion (Table I).

Table I. Fractionation of $\left[{ }^{3} \mathrm{H}\right]$ adenosine labeled RNA extracted from EDTA-dissociated polysomes by poly(U) Sepharose chromatography followed by partial digestion with pancreatic and $\mathrm{T}_{1}$ ribonuclease.

\begin{tabular}{ll}
\hline RNA fraction & $\begin{array}{l}\text { TCA precipitable } \\
\text { radioactivity } \\
\text { [cpm] }\end{array}$ \\
\hline total RNA & 7162 \\
RNA bound to poly (U) & 1636 \\
RNA not bound to poly (U) & 4180 \\
bound RNA after digestion & 354 \\
unbound RNA after digestion & 48 \\
\hline
\end{tabular}

Taking these results together it is reasonable to conclude that the structures released from polysomes by EDTA are mRNP particles containing heterodisperse RNA with poly (A) stretches. This view is supported by the buoyant density of the RNP particles elucidated in $\mathrm{CsCl}$ gradients (Fig. 3). While the absorbance profile shows only one peak at a density of $1.54 \mathrm{~g} / \mathrm{cm}^{3}$ corresponding to ribosomal subunits [7], radioactivity is found in two peaks at lower densities. For the main peak banding at $1.38 \mathrm{~g} / \mathrm{cm}^{3}$ a protein to RNA ratio of 1.5 is indicated [16]. This value compares well to that found for mRNP particles from several mammalian tissues [1]. Ajtkhozhin et al. [7] described three different classes of polysomal mRNP particles from wheat embryos according to their densities of 1.52, 1.46 and $1.40 \mathrm{~g} / \mathrm{cm}^{3}$, respectively. Takahashi et al. [3] reported a density of $1.40 \mathrm{~g} / \mathrm{cm}^{3}$ for newly synthesized free mRNP particles from pea embryos. The minor radioactivity peak in Fig. 3 banding at $1.45 \mathrm{~g} / \mathrm{cm}^{3}$ may represent mRNP particles associated with small ribosomal subunits as proposed for a similar structure from wheat embryos [7].

The data available so far on mRNP particles from higher plants indicate that these particles show a variety of size distribution patterns depending on the cellular fraction used to obtain these particles and on the plant material used. It is shown in this paper that polysomal mRNP particles from plant cell cultures exhibit a narrower range of sedimentation values than the corresponding particles found in germinating wheat embryos. The physiological significance of these differences is unclear, however. On the other hand, the buoyant densities of nuclear, free cytoplasmic and polysomal mRNP particles are similar to each other as well as to mammalian mRNP particles, supporting the idea of a closely related function in information transfer.

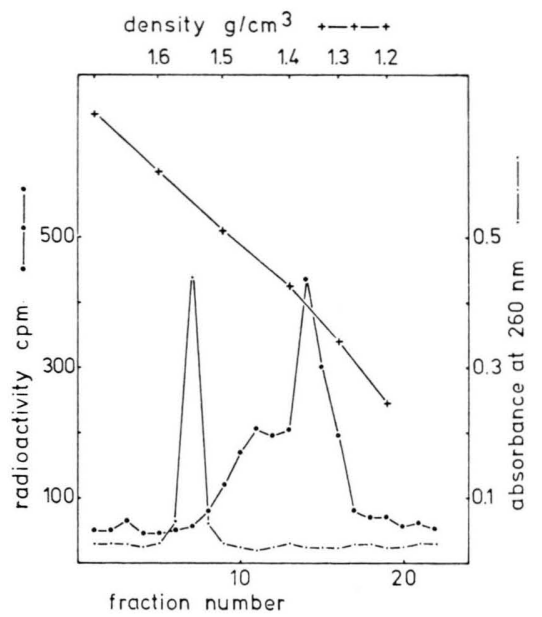

Fig. 3. Density distribution in a preformed $\mathrm{CsCl}$ gradient of RNP particles from EDTA-dissociated polysomes labeled with $\left[{ }^{3} \mathrm{H}\right]$ adenosine. Centrifugation was for $5 \mathrm{~h}$ at $178000 \times \mathrm{g}$ as described in Materials and Methods.

I am grateful to Dr. T. Gallagher for critical reading of the manuscript. This work was supported by a grant of the Deutsche Forschungsgemeinschaft to Prof. G. Richter, to whom I want to extend my gratitude. 
[1] D. Irwin, A. Kumar, and R. A. Malt, Cell 4, 157-165 (1975).

[2] P. I. Payne, Biol. Rev. 51, 329-363 (1976).

[3] N. Takahashi, F. Takaiwa, K. Fukuei, T. Sakamaki, and S. Tanifuji, Plant Cell Physiol. 18, 235-246 (1977).

[4] M. A. Ajtkhozhin, A. U. Akhanov, and Kh. Doschanov, FEBS Lett. 31, 104-106 (1973).

[5] M. A. Ajtkhozhin, N. S. Polimbetova and A. U. Akhanov, FEBS Lett. 54, 212-216 (1975).

[6] N. Takahashi, F. Takaiwa, F. Fukuei, T. Sakamaki, and S. Tanifuji, Plant Cell Physiol. 17, 1175-1184 (1976) .

[7] M. A. Ajtkhozhin and A. U. Akhanov, FEBS Lett. 41, $275-279$ (1974)

[8] G. Link and G. Richter, Biochim. Biophys. Acta 395, $337-346$ (1975).
[9] R. P. Perry, J. La Torre, D. E. Kelley, and J. R. Greenberg, Biochim. Biophys. Acta 262, 220-226 (1972).

[10] U. Lindberg and T. Persson, Eur. J. Biochem. 31, 246-254 (1972).

[11] M. Adesnik and J. E. Darnell, J. Mol. Biol. 67, 379406 (1972).

[12] D. Baltimore and A. Huang, Science 162, 572-574 (1968).

[13] J. Pfisterer and K. Kloppstech, Colloques Internat. du CNRS, No. 261, pp. 279-283, Editions CNRS, Paris 1977.

[14] A. Kumar and U. Lindberg, Proc. Nat. Acad. Sci. U.S. 69, 681-685 (1972).

[15] W. J. Peumans and A. R. Carlier, Planta 136, 195201 (1977).

[16] R. P. Perry and D. E. Kelley, J. Mol. Biol. 35, 37-59 (1968). 